University for Business and Technology in Kosovo

UBT Knowledge Center

Nov 7th, 9:00 AM - 5:00 PM

\title{
Comparative Analysis between the Istanbul House Plan Types and the Plan Types of the Ottoman Houses on the Panagia District in Kavala, Greece
}

Velika Ivkovska

Istanbul Technical University, ivkovska@itu.edu.tr

Follow this and additional works at: https://knowledgecenter.ubt-uni.net/conference

Part of the Architecture Commons

\section{Recommended Citation}

Ivkovska, Velika, "Comparative Analysis between the Istanbul House Plan Types and the Plan Types of the Ottoman Houses on the Panagia District in Kavala, Greece" (2015). UBT International Conference. 56.

https://knowledgecenter.ubt-uni.net/conference/2015/all-events/56

This Event is brought to you for free and open access by the Publication and Journals at UBT Knowledge Center. It has been accepted for inclusion in UBT International Conference by an authorized administrator of UBT Knowledge Center. For more information, please contact knowledge.center@ubt-uni.net. 


\title{
Comparative Analysis between the Istanbul House Plan Types and the Plan Types of the Ottoman Houses on the Panagia District in Kavala, Greece
}

\author{
Velika Ivkovska \\ Istanbul Technical University, Istanbul, Turkey \\ ivkovska@itu.edu.tr
}

\begin{abstract}
As part of the section on the Architectural History and the Architecture Values and Heritage, this paper will offer to the participants of the 4th IC ASPCE 2015 Durres Albania view on the development of the Ottoman House floor plans and its characteristics presented through the examples of the houses built in Istanbul between the 17th and 19th century and their comparative analy sis with the Ottoman houses built in the Panagia district in the Ottoman town of Kavala, Greece. The Ottoman House has its specific characteristics and a huge value that has a special place in the universal history of the house types. It is a type of house that can be found within the territories of the Old Ottoman Empire, in the territories of Rumeli and Anatolia. The goal of the paper is to conclude that the houses built in Ottoman Kavala, and that still exist in the old district of Panagia, have typical Ottoman floor plans emulgated with local influences and can be placed among the several ty pical architectural floor plan types of the Ottoman House.
\end{abstract}

Keywords: Ottoman house, typology of Ottoman house floor plans, sofali house, Vernacular architecture, Ottoman house in the Balkans, Istanbul houses, Ottoman Kavala

\section{Introduction}

This paper focuses on the development of the Ottoman House and its characteristics presented through the examples of the houses built in Istanbul and their comparative analy sis with the Ottoman houses built in the Panagia peninsula in the town of Kavala in Greece. Through an analy sis of the floor plans of the houses conclusions will be derived concerning the characteristics, origins and influences on the development of the Ottoman house outside the capital of the Empery.

\section{The Ottoman House}

The Ottoman house, that later became to be referred to as the Turkish house, is a type of house that can be find within the territories of the Old Ottoman Empire, in the territories of Rumelia and Anatolia. By the end of the $14^{\text {th }}$ century the Ottomans, conquered the European territory of Rumelia ${ }^{3}$. In these territories the Ottoman house was established and started its development. ${ }^{4}$ It is believed that its origins are set in Anatolia and then spread to Europe throughout the territory of the newly conquered Rumelia. ${ }^{5}$ The origins of the Ottoman house are still uncertain and matter of researches. The Turks, who were conquering these territories and originated from Middle Asia, were nomadic

3 Kurran A. 2012. Selçuklular'dan Cumhuriyet'e Türkiye'de mimarlık - architecture in Turkey from the Seljuks to republic. Türkiye İş Bankası Kültür Yay ınları. Istanbul. p.240-260

${ }^{4}$ Sedad Hakki Eldem in his book Turk Evi plan tipleri gives a detailed description of the development of the Ottoman house and its specific floor plans

5 The territory of Rumelia was the region of today's Bulgaria, Macedonia, Serbia, Bosnia and Herzegovina, some parts of today's Albania and Greece 
tribes who lived in tents ${ }^{6}$. After they arrived, in what once was Byzantine Kingdom, they faced an already existing architectural structures and an existing culture on the land that before was home of the Ancient Greeks art and architecture. The question of how the nomadic tribe's tent evolved into a hard material house is open even today. First the house was consisted of one space, the room, and later started to grow and slowely two, tree and four rooms were combined together forming the unity of the house- $e v$ but the functions of the rooms were still kept as in the single roomed house. This is one of the characteristic of the Ottoman house, the oda or the room. Each separate room contained all the daily functions of the household, unlike the Western houses, where each room had its own defined single function, one for sitting, one for sleeping, one for dining.

\section{The Floor Plan Typology of the Ottoman House}

A charachteristic of Ottoman town morphology was that the urban tissue was composed of not very large garden within the plot. The house plan was generated within the plot but encroached on the street, thus conditioning its architecture. The peculiarity of the Ottoman linkage of street patterns to building type consisted in its development on an axis perpendicular to the street, articulating the volumes in a free pattern from the street inwards. In the Ottoman house only the ground floor adapted to the site, invariably edging up to the street front, even when it was irregular.7 The concept of the room was something that defined the Ottoman house, that later as it continued to develop, it added other necessary features that also became elements of it. The story of the house is one of the elements specific for the Ottoman house. The house has the ground floor that is usually built in stone with entrance and small, or sometimes no windows at all, and the first floor or sometimes the top floor, in case of two storie houses, where the every day life was occuring. The stairs are another inseparable element of the Ottoman house. Up until the 18th and 19th century the stairs were located out of the external side of the hall. Later they were included in the floor plan inside the hall or between the rooms and started influencing the plan, gaining more importance and became more wide and spacious.8 One very important element of the Ottoman house is the hall called sofa . The rooms always open into the hall (sofa). If the room was to be compared with an individual house then the hall can be compared with the street and all the houses open onto it. Depending on the position of the hall and the way the rooms open onto it we can determine the floor types of the Ottoman house. This is how the four Ottoman house floor ty pes are distincted: house without a hall; house with an outern hall; house with an inner hall; house with a central hall.[Tab.1] The Ottoman's house classification is made according to their plan and not according to their order in time or to topographic and climate conditions. The reason for this is that these ty pes could not be attributed to certain periods or to certain regions, being independent of time and place. If a classification based on regional conditions 9 had to be drawn up, it would have to be made according to the degree of progress and advancement that the towns and villages, in which the houses were situated, had reached.10 These four floor type plans developed further on but keep the basic classification of the plan by the position of the hall. The various plan compositions were executed with divisions such as the Selamlik and Harem11, junctions that allowed increasment of the number of halls in the plan and also by adding pavilions (kiosks) at one or both ends of the hall.

\footnotetext{
${ }^{6}$ The word oda which means a room originated from the word otağ meaning tent

${ }^{7}$ Cerasi M. 1998. The Formation of the Ottoman House Types: A comparative study in interaction with neighboring cultures. Muqarnas Vol.15. BRILL. p.119

${ }^{8}$ Eldem S. H. 1954. Türk Evi Plan Tipleri. Istanbul Teknik Üniversitesi, Mimarlık Fakültesiç Istanbul. p. 219

${ }^{9}$ In his book Türk Evi Osmanlı Dönemi, Vol.1 S.E. Hakki gives a detailed explanation of the regional classification of the Ottoman house. There, he classifies the houses in seven groups. For more details on that see the refereed book p.30-32

${ }^{10}$ Eldem S. H. 1954. Türk Evi Plan Tipleri. Istanbul Teknik Üniversitesi, Mimarlık Fakültesiç Istanbul. p.220

${ }^{11}$ Bertram C. 2008. Imagining the Turkish house. University of Texas Press. Austin. p.30,31,250
} 

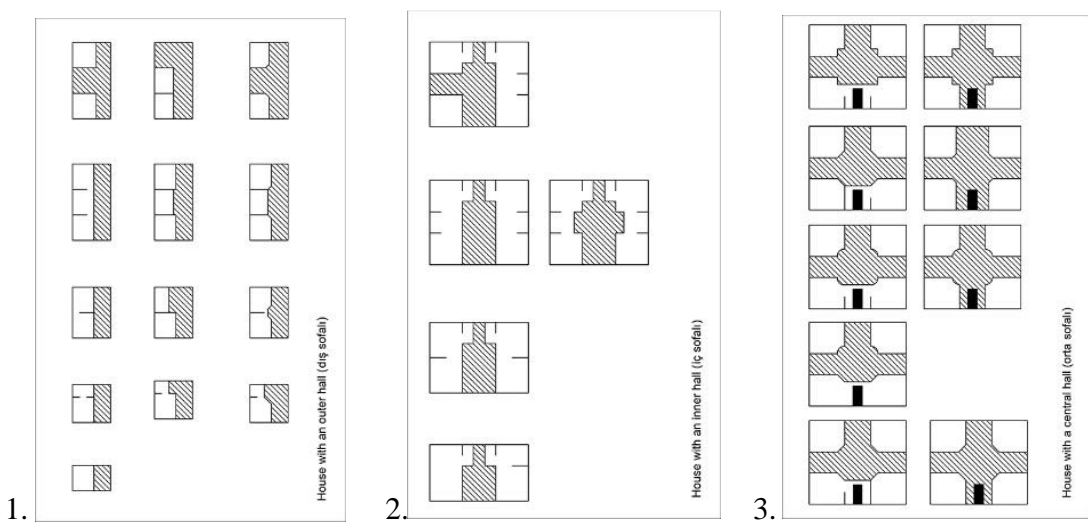

Tab. 1 House plan types with 1.outer hall; 2.inner hall; 3.central hall (redrawn from Eldem S. H. Türk Evi Osmanlı Dönemi. Cilt.1)

\section{Istanbul houses plan types in the 18th and 19th Century}

The regional classification of the Ottoman houses happened as a result of the different topographical, social and climate conditions. The Ottoman House found its classic being from Marmara and Rumelia regions and from places that were under the influence zones of these regions. Out of these two central regions, Marmara has dominated Rumelia, and Istanbul has dominated Anatolia. Istanbul and the Marmara region have special importance among the other six main house types regions. ${ }^{12}$ The Istanbul House can be considered as aty pical Turkish House while the house types of the other regions can be described as regional provincial types. Edirne comes also in the same group as Istanbul with the difference that the Edirne House type influence had spread towards Rumelia while Istanbul's influence embraced whole Anatolia. ${ }^{13}$ The majority of the buildings from the end of the $18^{\text {th }}$ and $19^{\text {th }}$ century built in these territories belong to the inner hall and central hall types. It is believed that very few of the buildings possessed an open hall. Central and axial halls were more popular. It is easy to understand why the earlier plan types in Istanbul were easily abandoned and made space for domination of the inner and central hall type.

The development of the Ottoman house can be followed in three periods. The first period studies the oldest form of the Ottoman house and starts somewhere in the $16^{\text {th }}$ century. During the $17^{\text {th }}$ century the houses were generally built with an open hall. The houses who had the sitting area on the first floor usually had the stairs on the outside of the façade and accessed the floor through the hall. This stairs were sometimes located within the hall. The house in the Istanbul's neighborhood Halicioglu [Tab.2] is a ty pical example of the Outern Hall floor ty pe and the house type from the first period that also included some elements of the second period. Numerous are the examples of this house type in Istanbul.
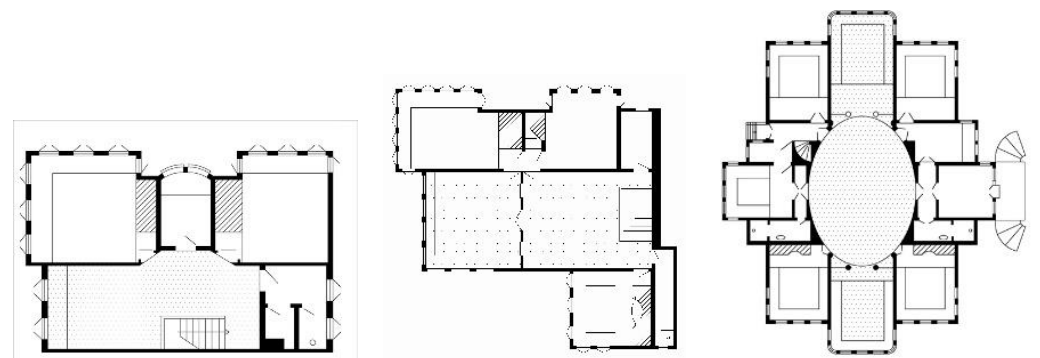

Tab. 2 Halicioglu neighborhood (Source: redrawn from Eldem S. H. Türk Evi Plan Tipleri) Tab. 3 House in Bebek, Istanbul (Source: redrawn from Eldem S. H. Türk Evi Plan Tipleri)

${ }^{12}$ See Hakki E.S. Turk Evi Osmanli Doneminde. p.31

${ }^{13}$ Ibid. p.31,32 
Tab. 4 Bebek, Istanbul. Plan of the Nispetiye Pavilion. End of $18^{\text {th }}$ century (Source: redrawn from Eldem S. H. Türk Evi Plan Tipleri)

The houses built in the $17^{\text {th }}$ century had the outer hall type that was typical for the first period. Unfortunately very few of these houses exist today. Some of them were demolished and some of them were lost by the time. The plan had its additions like pavilions that were erected at one [Table.3] or both ends of the hall. The houses of the second period were typical for the whole $18^{\text {th }}$ century. The house plan changed into the house with inner and central hall plan and the house with an open hall became unusual. This kind of hall was ty pical for Istanbul and spreads to the Marmara region. When the hall became enclosed freer arrangement of space was allowed. The first period house existed alongside the second period house for quite a time. ${ }^{14}$

The final development of the Ottoman house took place in the $19^{\text {th }}$ century. Most common floor type plan that was used in the third period was the inner hall plan. The halls started getting bigger in space and the stairs were given an important place in the plan. In this century baroque started to take its place within the house. Baroque curves were being presented through the oval hall and the curved doors that opened onto it. The inner elliptical hall was being popular since it was presenting social status and a symbol of a life-sty le in the metropolis. [Tab.4] This sty le was very much present in the Balkans even beyond the Empire style that replaced it in Istanbul when the elliptic halls started to disappear but were still present in the provinces.

\section{Historical Development of Ottoman Kavala}

The region of Rumelia was conquered by the Ottomans in ca. 1387. From that year up until the $16^{\text {th }}$ century, when Kavala became a vibrant port city due to the activities of the Ottoman Grand Vizier Ibrahim Pasha and the two sultans Selim I and Suleiman, we poses no source which fully establishes that there was a town in existence at its site. The earliest mention of a village/town named Kavala was found in an Ottoman tax register (tahrir defter) completed in the year 1478 (h.883) ${ }^{15}$ This means that ever since the date of the Ottoman occupation over these territories until the date of this tax register there is almost a one century gap in determining whether there was any sort of settlement on the site of the present day Kavala.

The Panagia district is the old historic nucleus of Kavala. Its boundaries are defined by natural and artificial features as the cliffs, the harbor, the city wall and the aqueduct. The district consists of a number of localities, whose individual characters are a result of historical evolution, the configuration of the terrain and the way they are incorporated into the urban area of Kavala as a whole. ${ }^{16}$ Inside the old nucleus five defined localities can be determined. Even though the Panagia district may be described as a unified urban unit, with a close examination of the settlement there is an existence of distinct sub districts. [Tab.5]

\footnotetext{
${ }^{14}$ Eldem S. H. 1984. Türk Evi Osmanlı Dönemi. Cilt.1. Türkiye Anıt Çevre Turizm Değerlerini Koruma Vakfi. p.135-147

15 Lowry W.H. 2008. The shaping of the Ottoman Balkans 1350-1550. Bahcesehir University Publications. Istanbul

${ }^{16}$ Kavala Intra Muros: Spatial readings and Architectural Proposals, Demos Kavala, 1992
} 


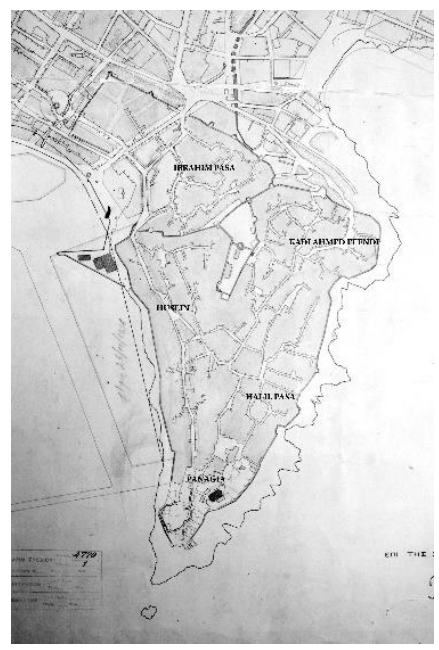

Tab. 5 Urban Plan of the Panagia district, Kavala from 1923 (Courtesy of the Municipality of Kavala, Sector for Urban Planning) (Source: Author's archives, 2015)

The residential enclaves in the Panagia district are of various shapes and sizes. An examination on how the buildings are positioned in the urban fabric shows that they are organized in two ways: either as free standing units or in linear disposition along an axis. The internal development of the fabric which is now brought about by the neo-traditional buildings which are being erected without reference to historical ty pology is leading to a gradual change in the original composition. The relations between the buildings determine the overall profile of the district, most important of all being the direction of the buildings main axes. ${ }^{17}$ [Fig.1]

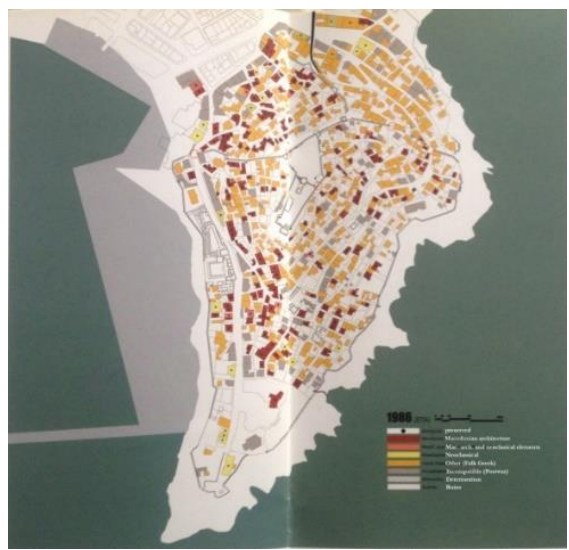

Fig.1 The map was designed following the framework features from 1962

A typological and morphological examination of the buildings makes it possible to assess their particular qualities and characteristics. A research conducted by the University of Aristotle lead to certain conclusions about the typology of the houses. By a close examination of the plans three basic types were set. Types A, B and C.

${ }^{17}$ Ibid, p.63 

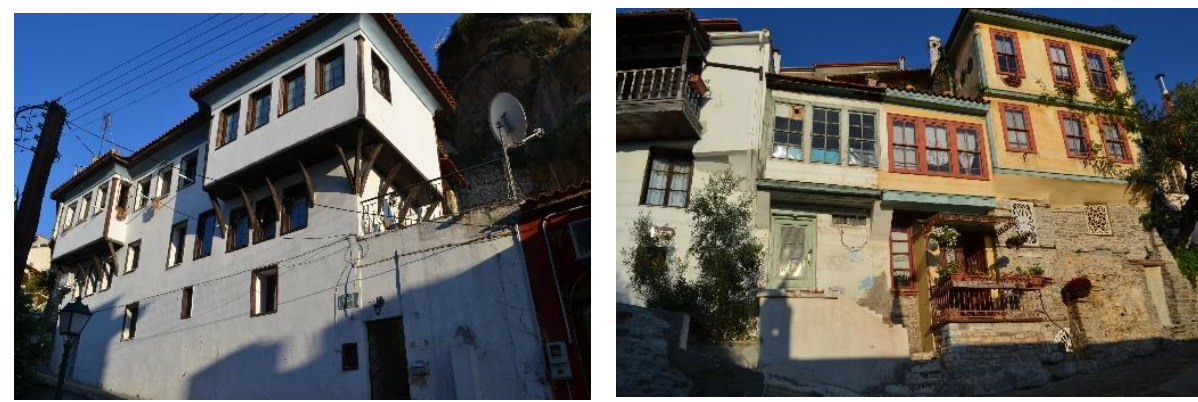

Fig.2 House in Panagia district on Mehmed Ali Street (Source: Author's archives)

Fig.3 House in Panagia district on Polidou Street (Source: Author's archives)

The type A is a house with two rooms; one closed one semy-open. The most simple ty pe in the Panay ia district is the two storey building with a closed balcony - sitting room and a vertical access in a form of a staircase (Type A1).This balcony is actually the outer hall that we find in the first period of the Ottoman houses in Istanbul. The other more common is the A2 type with broader front, usually with 2 rooms next to each other and an enclosed area (balcony-sitting room) where the stairs are located. The A3 type is with even more broad front and has 3 or more rooms in a row fronted by a spacious sitting room. From the floor plan analy sis of the so called A type we can conclude that this type of a house has an outer hall which is closed and from which we access the room or the rooms. The stairs are placed inside this hall. [Tab.6]
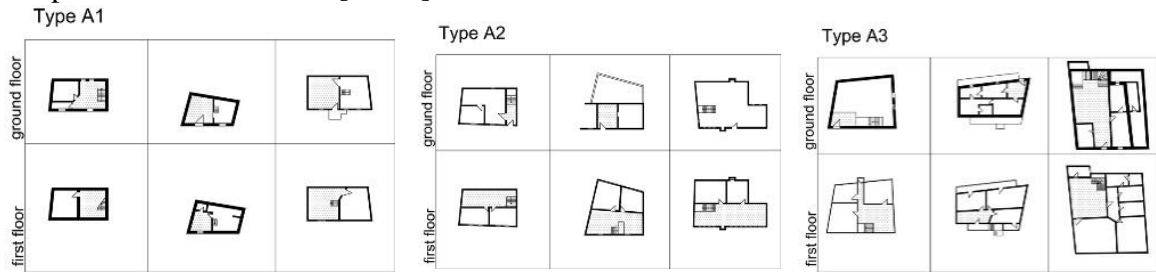

Tab.6 Type A house plans (Source: redrawn from Kavala Intra Muros: Spatial readings and Architectural Proposals, Demos Kavala, 1992)

Type B is essentially a product of evolution of the parceling system and successive division of urban land. The buildings are two stores, narrow-fronted structures presenting a limited area towards communal spaces. [Tab.7] The type $\mathrm{C}$ is probably more recent and is more urban in character. It comprises two-story, box shaped or broad-fronted buildings with more morphological features. The one feature in common to all variations of this type is the internal central sitting room with the rooms positioned symmetrically on either side of it. The type $\mathrm{C}$ presents the inner hall floor plan as we presented in the examples from the second period of the development of the Ottoman house in Istanbul. The long inner hall spreads in the middle of the house and the position of the stairs is sometimes at one end of it or in the middle. [Tab.7]
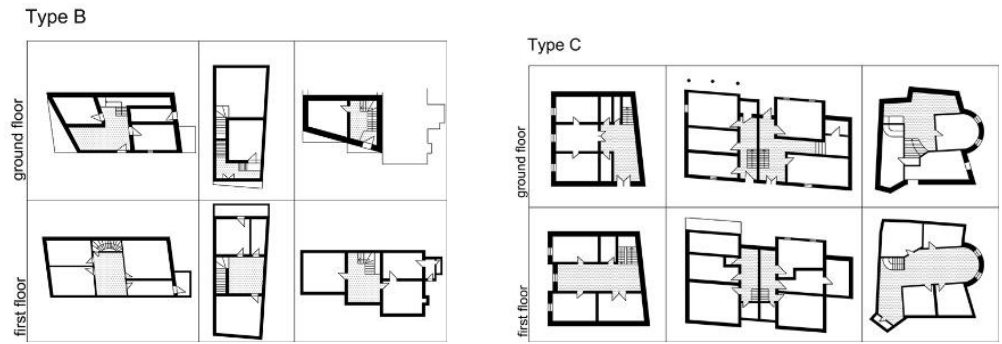

Tab. 7 Type B and C type plans (Source: Kavala Intra Muros: Spatial readings and Architectural Proposals, Demos Kavala, 1992) 
Given the examples from the plan types in Ottoman Kavala we notice that the central hall plan doesn't appear in the typology of the houses in the town. If the style itself presented nobility and social development than we can conclude that the town, until the tobacco industrial explosion, kept its provincial character.

The Mehmed Ali's house, the founder of the Egyptian dynasty's house can be taken and presented separately because of its owner's importance not just to Kavala also to the Ottoman period and the Egyptians which last dynasty he ruled. The house was owned by his maternal grandfather and Mehmed Ali lived here after his parent's deaths. ${ }^{18}$ Probably in the eighteenth century Mehmed Ali's house was one of the towns very important and obviously few mansion houses. Typologically it is a traditional broad fronted two story residence with a linear lay out of rooms and a balcony cumsitting room on the first floor and auxiliary areas and covered courtyard below. [Tab.8] The house of Mehmed Ali is one of the few remaining residences in Greece which preserve the separate men's and women's quarters (selamlik and harem respectively), which were some of the chief characteristic of the Turkish Houses of the well situated families. Additions and alterations have not affected the basic typological coherence of the building, which is now a museum. ${ }^{19}$ The house was restored in $2001 .^{20}$ This house presents atypical Ottoman mansion. It is built on the steep terrain on the east side. Lying on a solid rock over which a stone ground floor was built above which lies the beautiful light wooden top floor with incredible plasticity of the bay windows. [Fig.4]

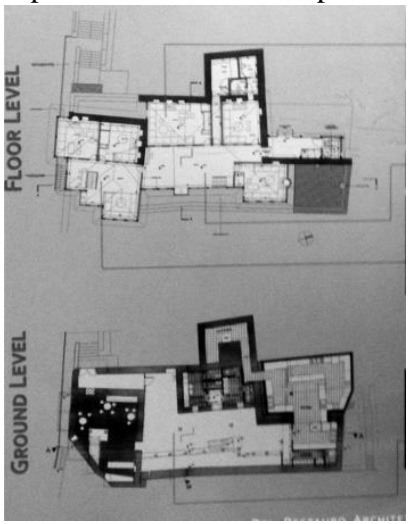

Tab.8 Floor plans of the Mehmed Ali's

2001(Source: Imaret Hotel)

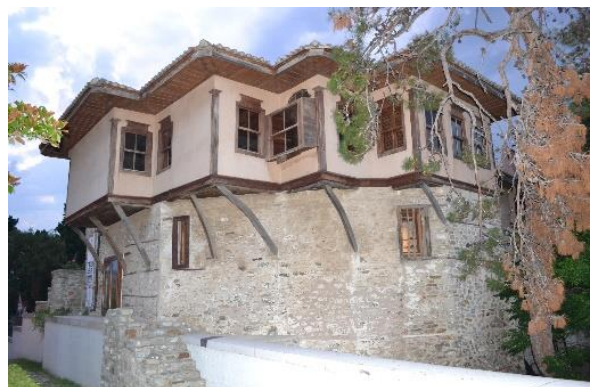

Fig.4 Mehmed Ali's House (Source: Author's house for its reconstruction in archives, 2014)

\section{Conclusion}

The Ottoman vernacular style in general had undergone three major stages of development. It is known very little of the domestic forms from the $15^{\text {th }}$ and $16^{\text {th }}$ centuries. This is why an analysis of the development of the Ottoman house types cannot be taken further back than the $17^{\text {th }}$ century. The development can be followed in three phases that correspond to three distinct types. The first phase

${ }^{18}$ Lowry W.H. Ersunal I. 2011. “Remembering One's Roots “Mehmed Ali Pasa of Egypt's links to the Macedonian town of Kavala: Architectural Monuments, Inscriptions \& Documents. Bahcesehir University Press, Istanbul. p.1-10

${ }^{19}$ Kavala Intra Muros: Spatial readings and Architectural Proposals, Municipality Kavala, 1992, p.65

${ }^{20}$ Anna Misirian Tzouma is native of Kavala and the owner and manager of Imaret A.S and the Imaret Hotel. It took six yearlong efforts to gain permission from the Egyptian's Government's Waqf Administration to fully restore the Imaret and use the monument as a hospitality and culture venue. In 2001 a contract was signed which allowed the restoration of Mehmed Ali's complex to begin but the agreement also stipulated that restoration of Mehmed Ali's home must be undertaken too. (in Lowry W.H. Ersunal I. 2011. "Remembering One's Roots "Mehmed Ali Pasa of Egypt's links to the Macedonian town of Kavala: Architectural Monuments, Inscriptions \& Documents. Bahcesehir University Press, Istanbul. p.23) 
is the $17^{\text {th }}$ century house, the second the $18^{\text {th }}$ century and the third, the $19^{\text {th }}$ century. These phases it is believed that have their roots in Istanbul and then spread over the Marmara region and had their secondary influences in the further geographical territories of the Ottoman Empery. Some of the types from previous periods still continued to live parallel with the contemporary style, but mostly these older house types prevailed in the provinces. That is why this three period division of the types by centuries can only be applicable to Istanbul.

In the town of Kavala, from analy zing the houses floor plans, we can follow the development of the house and determine few ty pes of floor plans. Some of them correspond with the earlier development of the area due to their lack of space and modest development in its interiors. As for the houses with wider floor plans we can come into conclusion that as first they were built probably in the later centuries of the Ottoman rule, when the tobacco industry was in its bloom, so it allowed the rich owners to be able to build wider houses and build them in a more wider land plots that allowed expanding the floor plans, that unlike the other types who only had major sun and light income at the upper floors, and were not limited in their floors. The specific of the terrain and the location of the settlement made direct impact on the floor types of the houses that became a mixture of the Ottoman houses with implementation of local traditions and directed by their positioning on the terrain. The richness of the architectural elements that can be seen in this location are of exceptional importance since they show the ways how the builders in those times were solving problems in order to design and built houses that will provide not just the basic needs for shelter but also commodity, view and light. The Ottoman house in Istanbul had its development stages through the centuries which we can follow as far as the $17^{\text {th }}$ century. The Istanbul house had its 3 major phases of development that happened in the 3 following centuries respectively. Sometimes the previous style lived together with the newly developed but slowly started disappearing and leaving completely space for the newly formed style. This was not the case with the provinces though. Kavala being also one of the Ottoman provinces, just like most of the towns in Rumelia, still kept its later styles. This is why the division of the style development by centuries can only be applied to Istanbul but not the other provinces of the Ottoman Empery.

Istanbul, being the metropolis had its life style and specific vernacular architecture that developed with the influence of the society, the income and with the whole glory of the capital itself. In the case of the town of Kavala the most respective noble from the Ottoman period and not considering the late $19^{\text {th }}$ century house development in Kavala, was Mohamed Ali, the founder of the Egyptian dynasty. His house is the only one in Kavala built as a mansion with the specific architectural characteristics of a wealthy family. The other houses in the old peninsula that are preserved, but yet were a matter of interventions, kept its "provincial" characteristics. Being very densely populated the plots were very small, sometimes narrow and also positioned on the sloppy terrain that added to the difficulty of having wider or at least clearer forms of plots. This was not the case with the houses that were built by the middle and the end of the $19^{\text {th }}$ century when the tobacco industry started to flourish in Kavala, when many foreign traders settled in the town and built their houses and brought with them the western influences. But it is important to mention that these new houses were built in the new area outside of the walled, overcrowded Panagia district.

In the Panagia district all the Ottoman House elements are present and visible, the urban layer of the peninsula kept its Ottoman organic structure with interventions made in the later centuries as necessary to the new life styles, the development of the town and the industrialization, but yet those urban interventions are noticed only in widening the main streets of the peninsula that existed in the Ottoman era. It is not negotiable that the Panagia district in Kavala was a typical Ottoman town with its urban and architectural specifics. The town was built on a land where a Byzantine town was existing which, after got taken by the Three Beys ( $\ddot{U} c ̧$ Beyler) in 1387, was burned to ground and there was no evidence of a settlement nearly for a century. This means that Kavala was a fresh, new Ottoman town build on an empty plot or area and no local or previous existing influences could have been possible to impact the house development due to the fact that there was no settlement and no life for nearly a century. 


\section{Acknowledgements}

"This paper has been presented with the support of the Turkish Cultural Foundation. The contents of the publication are the sole responsibility of the author, Velika Ivkovska, and can in no way be taken to reflect the views of the Turkish Cultural Foundation."

\section{References}

1. Akin, N. Balkanlarda Osmanlı Dönemi Konutları. Literatur, Istanbul

2. Ayverdi E. H. Avrupa'da Osmanlı Mimari Eserleri (Bulgaristan, Yunanistan, Arnavutluk) IV.Cilt. Istanbul (2001)

3. Bechhoefer, W. Visions of Place. University of Mary land (2010)

4. Bertram, C. Imagining the Turkish house. University of Texas Press. Austin (2008)

5. Celebi, E.1968. Travels. Vol 1, Vol 2. London

6. Cerasi, M. The Formation of the Ottoman House Types: A comparative study in interaction with neighboring cultures. Muqarnas Vol.15. BRILL (1998)

7. Doğan, K. Türk Hay atlı Evi. Eren Yay ıncılık. Istanbul (1995)

8. Günay, R. İstanbul'un Kaybolan Ahşap konutları.YEM. Istanbul (2014)

9. Eldem, S. H. Türk Evi Osmanlı Dönemi. Cilt.1. Türkiye Anıt Çevre Turizm Değerlerini Koruma Vakfi (1984)

10. Eldem, S. H. Türk Evi Plan Tipleri. Istanbul Teknik Üniversitesi, Mimarlık Fakültesi. Istanbul (1954)

11. Kurran, A. Selçuklular'dan Cumhuriy et'e Türkiye'de mimarlık - architecture in Turkey from the Seljuks to republic. Türkiye İş Bankası Kültür Yayınları. Istanbul (2012)

12. Lowry, W.H. The Shaping of the Ottoman Balkans 1350-1550. Bahcesehir University Press. Istanbul (2008)

13. Lowry, W.H., Ersunal I. "Remembering One's Roots”Mehmed Ali Pasa of Egypt's links to the Macedonian town of Kavala: Architectural Monuments, Inscriptions \& Documents. Bahcesehir University Press. Istanbul (2011)

14. Lowry, W.H. In the footsteps of Evliy a Celebi. Bahcesehir University Press. Istanbul (2012)

15. Schreiner, P. Die Byzantinischen Kleinchroniken, Vol.XII.Vienna (1977)

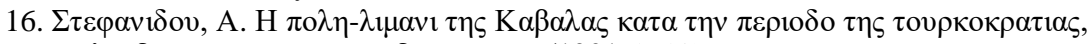

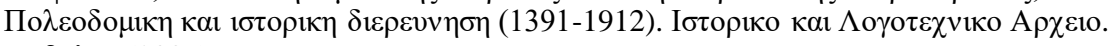
$\mathrm{K} \alpha \beta \alpha \lambda \alpha \varsigma$ (2007)

\section{Bulletins}

Kavala Intra Muros: Spatial readings and Architectural Proposals, Municipality Kavala, (1992)

Know how Networks, Research Committee AUTH- School of Architecture, Kavala Intra Muros: mobility (2006)

Kavala one destination, a kaleidoscope of experiences, Gazette of Municipality of Kavala 